\title{
Developing a Carbon Baseline to Support Multi-Stakeholder, Multi-Level Climate Governance at County Level
}

\author{
Erica Russell and Ian Christie
}

Highlights Orchestration requires political commitment and engagement on the basis of evidence, knowledge and progress-checking. Local actors face challenges in compiling carbon baselines that offer useful production and consumption emissions.

Keywords County · Baseline · Carbon emissions

\section{The Importance of Local Baseline Data}

There is widespread acceptance that top-down approaches to climate change, identified with the Kyoto Protocol (Jordan et al., 2018, p.4), are no longer sufficient to drive climate action. International bodies,

E. Russell $(\varangle)$. I. Christie

Centre for Environment and Sustainability (CES), University of Surrey, Guildford, UK

e-mail: erica.russell@surrey.ac.uk

(C) The Author(s) 2022

C. Howarth et al. (eds.), Addressing the Climate Crisis, https://doi.org/10.1007/978-3-030-79739-3_6 
such as the UN, are seen as providing global direction, but with the Paris Agreement came an acceptance that implementation based on 'real world' experimentation required greater action by state, sub-state and non-state organisations (Oberthür, 2016). This shift in thinking has seen increased debate about effective governance forms: those focused on mutually interdependent national and sub-national actors; the multilevel governance approach first identified by Hooghe and Marks (1996); and the related concept of polycentricity, which focuses on local leadership through self-coordinating groups, often as part of wider networks (Ostrom, 2014; Backstrand et al., 2018). Increasingly, a need for both approaches has been cited, as capacity, resources and reach need to be shared (Newell et al., 2012). It is within a context of frequently 'uncoordinated' sub-national action (Bansard et al., 2017) that this chapter considers a strategically significant issue for climate policymaking and for 'orchestration' of climate governance (Backstrand et al., 2018)—namely, the difficulties of creating an effective emissions baseline suitable for local actors to use as a basis for climate mitigation planning and implementation. Specifically, we consider the county level of local action in the UK, focusing on Surrey, a county in England.

\section{Establishing a Carbon Baseline for Surrey}

Carbon footprinting and baselining exercises have been completed for many cities, including several in the UK, but little research has been undertaken at larger sub-national scales. This case study offers insights from the carbon baseline work initiated by the Surrey Climate Commission and undertaken by the Centre for Environment and Sustainability at the University of Surrey. (This exercise complements recent carbon footprinting work carried out for Surrey County Council.) The Surrey experience sheds light on issues arising in efforts to provide crucial climate-related information for a territory that includes large urban populations, extensive suburban areas and a substantial rural population and area. Working at the scale of a county creates both complexity and opportunities. Surrey is adjacent to London, with a population of approximately 1.2 million who live in its 26 towns, 175 villages and hamlets. The county

I. Christie

e-mail: i.christie@surrey.ac.uk 
comprises large areas of downland and sandy heath, and is highly wooded ( $22 \%$ of area), and farming tends to be extensive.

Surrey is administered through multiple tiers: a county council, 11 borough and district councils, and more than 80 parish and town councils and is part of two wider sub-regional Local Enterprise Partnerships. Surrey also has strong advocacy groups, with over 50 organisations involved in environmental or climate activities (Street, 2020). Whilst this degree of institutional richness may be a local strength, supporting both multi-level and polycentric approaches to climate governance, risks arise. Without a clear vision for coordination and long-term planning, such a plethora of actors can result in confused responsibility and reduced impact in environmental and climate policy (Newell, Pattberg $\&$ Schroeder, 2012). This complexity poses challenges in carbon baseline studies distinct from those arising for cities.

Drawing together this diversity of actors and county attributes, the Surrey Climate Commission provided a leadership role, acting as both the initiator and an independent actor (Homsy \& Warner, 2015) in requiring a baseline study. Accepting that limited information results in poorly targeted climate action plans (Boehnke et al., 2019; Lehtonen \& Kern, 2009), a local and relevant emissions baseline was seen as critical for highlighting carbon 'hotspots'. Failure to overcome deficiencies in localised data and action planning was also identified as restricting the development of best practice (Boehnke et al., 2019). As a result of these constraints, there is little evidence that increased capacity for local climate action has resulted in actual reductions in local carbon emissions (Hoppe et al., 2016), a situation the Surrey Climate Commission wanted to address.

With political and financial limitations in mind, a primary aim of the baseline research was to use readily accessible publicly available data that would allow for ease of ongoing monitoring at little additional cost or expertise. Where possible, the research utilised sub-national emissions datasets (BEIS, 2020b) to provide quality assurance and to align with the local authority reporting frameworks. Working at the county scale, the baseline had to consider land use, with its potential for carbon capture, high levels of variation in district profiles, both physical and population based, and in the case of Surrey, the impact of London commuting and wealth transfer. Key to the engagement of local actors was the provision of a baseline carbon footprint that offers this nuanced understanding of place, local issues and interest group alignment. Whilst local climate 
action by public bodies has focused primarily on territorial emissions, the Surrey Climate Commission's members made it clear, through a process of consultation, that the baseline work must additionally incorporate and highlight the impacts of consumption as well as of local emissions from production.

\section{Issues Encountered in Creating}

\section{a Useful County-Scale Baseline}

The Surrey Climate Commission baseline research project has identified several issues in creating county-scale baselines that we expect would face similar county or sub-regional level work. Most importantly, national datasets, even those available at a sub-national level, are based on international emissions reporting commitments and national government policy needs. It is clear that multiple reporting formats have created discrete UK carbon datasets. Some of these are spatially separated, and others use different methodologies, data and extensive modelling to provide insight into specific sectors or issues. Even direct energy use data lack granularity, with BEIS acknowledging that an annual spend threshold may mean a misallocation of up to 2 million small businesses as domestic users (NAEI, 2020). Information is also held in different measurement units and carbon formats. Such variation in methodologies makes direct comparison difficult.

UK Sub-National Consumption statistics (BEIS, 2019b) provide emissions data for four fuel categories: electricity, gas, other heating fuels and transport fuel, allocated across three territorial categories: domestic, industrial/commercial and transport. Additionally, they provide data on land use, for both carbon emissions and sequestration. All emissions are supplied in units of $\mathrm{CO}_{2}$ and are available at both county and district levels. This information provides a useful guide to county-based carbon hotspots. However, the UK Carbon Footprint (DEFRA, 2019), based on models using value flows, is currently only available at a national level.

\section{Addressing Baseline Limitations}

To overcome the disconnect between this top-down data availability and the types of information needed to support practical, local action, the researchers worked with the Surrey Climate Commission to identify key areas to expand as part of the Surrey baseline: 
1. Enhanced spatial and use detail of people's homes and Surrey travel;

2. Identify the local impact of business and the public estate;

3. Increase understanding of the land and its role in carbon sequestration;

4. Estimate the size of the county's carbon footprint.

In doing this, an important principle was established: namely, that with increased granularity came a coarsening of the data, but that this trade-off was acceptable if it provided richer insight, supported proportionality of response, identified gaps and made visible unseen issues. The following sections provide examples of this work.

\section{Creating Richer Insight}

The highest territorial emissions in Surrey are associated with transport and travel (50.2\%). Sub-regional data (BEIS, 2020b) confirm that traffic on Surrey's A-roads and motorways generate the greatest emissions, but provide no detail on what types of vehicles are creating the emissions-or why the vehicles are being driven. The most detailed information on work patterns and commuting at an individual level is the Census dataset. Using this, it was possible to understand local work and commuting patterns by distance and transport type, albeit with the caveat that this information is now dated. The data are even less reliable as a guide to the future as a result of COVID-19, which has expedited changes in shopping patterns and an increase in working from home, shifts which are unlikely to be completely reversed after the virus effect is overcome. Car usage was the primary generator of emissions on all types of roads, creating between 52 and $70 \%$ of Surrey districts' transport emissions. Combining 'reason to travel' national survey data (DfT, 2018) with calculated Surrey car emissions enabled a crude allocation of Surrey resident travel. This suggested that whilst home working could reduce commuting-related emissions, up to $33 \%$ of car-based emissions were generated in visiting friends and family. Here, reduction may require low carbon travel alternatives.

As noted earlier, information on domestic electricity and gas emissions is available at a tier 2 level but additional work using domestic Energy Performance Certificate (EPC) data (MHCLG, 2019) provided a more nuanced guide to the types of homes in each district and average emissions. This analysis indicated a strong correlation between house size, affluence and higher emissions usage. Whilst many councils have focused 
on the social co-benefits achieved by supporting those in fuel poverty, this work identifies that there is an ongoing need to promote behavioural change among those citizens most able to afford carbon reduction.

\section{Offering Perspective on the Scale of Emissions}

Many public bodies have taken on a leadership role in decarbonisation in their own estate, promoting energy demand reduction, testing new technologies at scale or undertaking large exemplar renewable projects. It is important that local actors have a realistic perspective on the direct impact such activity can have at a county level. This is difficult, as BEIS sub-national data do not differentiate public sector emissions from those of industry and commerce. Our attempts to estimate county emissions from the public sector, using locally available data for Surrey, were only partially successful. Whilst the County Council, the University of Surrey and NHS primary healthcare sites could provide annual emissions data, those for district councils were incomplete; and information on emissions from secondary healthcare sites was extremely limited. We concluded that the public sector accounted for around $2 \%$ of the county's total emissions, although it is likely that this is an underestimation. It is, however, in line with published UK national public sector emission estimates (BEIS, 2020a).

For local organisations wanting to drive change within industry and commerce (19.3\% of Surrey $\mathrm{CO}_{2}$ emissions), where and why these emissions occur remains a difficult question to answer. Whilst ONS subnational data include energy and travel emissions for the agricultural sector, ONS offers no granularity for other sectors. To overcome this, our baseline work drew together national business emissions for both $\mathrm{CO}_{2}$ and $\mathrm{CO}_{2} \mathrm{e}$ by sector (ONS, 2019a), national business numbers by sector (BEIS, 2019a) and numbers of businesses by sector in Surrey (ONS, 2019b). Carbon dioxide emission data suggest that manufacturing businesses create the highest sectoral emissions (45\%) across all but one of the county's districts, whilst the logistics sector $(22.6 \%)$ is significant in one of the districts. The baseline study also reviewed industry $\mathrm{CO}_{2} \mathrm{e}$ emissions: here it seems that there is considerable under-reporting of emissions within agriculture, forestry and fishing, and more substantially in the manufacturing sector, where more than $80 \%$ of emissions identified are derived from gases other than $\mathrm{CO}_{2}$. Other sectors are less affected, appearing to emit around $90 \%$ of their carbon as $\mathrm{CO}_{2}$. 


\section{Identifying Gaps}

In 2018, ONS data confirmed that Surrey land acts as a carbon sink. Expanded information available at a local authority level now provides positive and negative emissions from four types of land use (BEIS, $2020 \mathrm{~b}$ ). This offers increased granularity of data on carbon sequestration due to local land use change, indicating the benefit of increasing woodland, peat wetlands and grassland. However, the dataset only enables high level monitoring of land use change, which limits the use of data in informing strategy and driving action. This gap is being investigated further.

\section{Making Hidden Impacts Visible}

To understand the 'hidden' carbon impact of products and services bought by those living and working in Surrey, the research attempted to allocate national footprint data. Simple pro-rata allocation by population size did not allow for the impact of affluence, an issue highlighted in the Surrey homes data, which would result in an underestimation of consumption emissions. Therefore, we adapted and updated the work of Minx et al. (2013), who combined both MRIO data with information on a variety of metrics linked to affluence: this approach suggests a carbon footprint of $16,898 \mathrm{ktCO}_{2}$. Whilst a relatively crude allocation, this would certainly suggest that Surrey's overall carbon footprint, combining the production and consumption perspective, is at least twice the size of the territorial emissions.

\section{CONCLUSION}

With an acceptance that climate change action is a responsibility of all, we argue that polycentric approaches need to be underpinned by knowledge at all levels. The challenges of place-based climate action at local levels in the UK and beyond are multifaceted, and effective action depends on a good base of knowledge to help decision-makers navigate the complexity. Whilst there is much to welcome in ground-up action, we suggest that a level of orchestration is required. National datasets need to be improved as indicated in our earlier discussion. But a crucial additional task for central government with actors at sub-national scale is to ensure that national data are complemented by adequate resources to enable local 
authorities and their partners to establish and update datasets on sectoral emissions at city, county and district/borough level. We suggest too that work needs to be done on development and take-up of a standard set of carbon mapping tools and metrics at local scales, to enable comparisons, collaborations and information exchange between actors in climate governance at local and regional levels. Finally, urgent work is needed on measuring progress in reducing emissions from consumption. Given the extent of diversity and inequality in local economic and social conditions, we suggest there is great value in locating that work primarily at local levels. We recommend that central government equip a variety of local authorities to act as centres of excellence in mapping and measuring progress in reductions in lifestyle-based emissions (these areas could well be drawn from those that have set up PCAN Climate Commissions).

\section{REFERENCES}

Bäckstrand, K., Zelli, F., \& Schleifer, P. (2018). The legitimacy and accountability in polycentric climate governance. In A. Jordan, D. Huitema, H. van Asselt, \& J. Forster (Eds.), Governing climate change: Polycentricity in action (pp. 338356). Cambridge University Press. https://doi.org/10.1017/978110828464 6.020

Bansard, J. S., Pattberg, P. H., \& Widerberg, O. (2017). Cities to the rescue? Assessing the performance of transnational municipal networks in global climate governance. International Environmental Agreements: Politics, Law and Economics, 17(2), pp. 229-246.

BEIS. (2019a). Business population estimates 2019. Available at: https://www. gov.uk/government/statistics/business-population-estimates-2019. Accessed: 29 January 2020.

BEIS. (2019b). Sub-national consumption statistics methodology and guidance booklet. London. Available at: https://www.gov.uk/government/publicati ons/regional-energy-data-guidance-note

BEIS. (2020a). 2018 UK greenhouse gas emissions, final figures. London. Available at: https://assets.publishing.service.gov.uk/government/uploads/sys tem/uploads/attachment_data/file/862887/2018_Final_greenhouse_gas_ emissions_statistical_release.pdf

BEIS. (2020b). UK local authority and regional carbon dioxide emissions national statistics: 2005 to 2018. London: BEIS. Available at: https://www.gov.uk/ government/statistics/uk-local-authority-and-regional-carbon-dioxide-emissi ons-national-statistics-2005-to-2018

Boehnke, R. F., et al. (2019). Good practices in local climate mitigation action by small and medium-sized cities; exploring meaning, implementation and 
linkage to actual lowering of carbon emissions in thirteen municipalities in The Netherlands. Journal of Cleaner Production, 207, 630-644.

DEFRA. (2019). UK's carbon footprint 1997-2016. London. Available at: file://C:/Users/User/Documents/UK Carbon Footprint 1997-2016.pdf.

DfT. (2018). National travel survey: England 2018. London. Available at: https://assets.publishing.service.gov.uk/government/uploads/system/ uploads/attachment_data/file/823068/national-travel-survey-2018.pdf. Accessed 9 June 2020.

Homsy, G. C., \& Warner, M. E. (2015). Cities and sustainability: polycentric action and multilevel governance. Urban Affairs Review, 51(1), 46-73.

Hooghe, L., \& Marks, G. (1996). "Europe with the regions": Channels of regional representation in the European Union. Publius: The Journal of Federalism, 26(1), 73-92.

Hoppe, T., Van der Vegt, A., Stegmaier, P. (2016). Presenting a framework to analyze local climate policy and action in small and medium-sized cities. Sustainability, $8(9), 847$.

Jordan, A., et al. (2018). Governing climate change: Polycentricity in action? Cambridge University Press.

Lehtonen, M., \& Kern, F. (2009, Springer). Deliberative socio-technical transitions. In Energy for the future (pp. 103-122). Palgrave Macmillan.

MHCLG. (2019). Table EB7: Domestic Energy Performance Certificates for existing dwellings by type of property, average energy use, carbon dioxide emissions and fuel costs, Statistical data set Live tables on Energy Performance of Buildings Certificates. Available at: https://www.gov.uk/government/sta tistical-data-sets/live-tables-on-energy-performance-of-buildings-certificates.

Accessed 18 February 2020.

Minx, J., et al. (2013). Carbon footprints of cities and other human settlements in the UK. Environmental Research Letters, 8(035039), 1-10.

NAEI. (2020). Local and regional carbon dioxide emissions estimates for 20052018 for the UK. London. Available at: https://www.gov.uk/government/ statistics/uk-local-authority-and-regional-carbon-dioxide-emissions-nationalstatistics-2005-to-2017

Newell, P., Pattberg, P., \& Schroeder, H. (2012). Multiactor governance and the environment. Annual Review of Environment and Resources, 37.

Oberthür, S. (2016). Reflections on global climate politics post Paris: Power, interests and polycentricity. The International Spectator, 51(4), 80-94.

ONS. (2019a). Atmospheric emissions: greenhouse gases by industry and gas: Total greenhouse gas emissions by industry section, 1990 to 2017 and (provisional) 2018. Available at: https://www.ons.gov.uk/economy/environmentalaccou nts/datasets/ukenvironmentalaccountsatmosphericemissionsgreenhousegase missionsbyeconomicsectorandgasunitedkingdom. Accessed: 29 January 2020. 
ONS. (2019b). Number of businesses in Surrey. Available at: https://www.surreyi. gov.uk/dataset/24jw6/number-of-businesses-in-surrey. Accessed: 29 January 2020.

Ostrom, E. (2014). A polycentric approach for coping with climate change. Annals of Economics and Finance, 15(1), 97-134.

Street, P. (2020). Vision for sufficient action in Surrey. Guildford.

Open Access This chapter is licensed under the terms of the Creative Commons Attribution 4.0 International License (http://creativecommons.org/licenses/ by $/ 4.0 /)$, which permits use, sharing, adaptation, distribution and reproduction in any medium or format, as long as you give appropriate credit to the original author(s) and the source, provide a link to the Creative Commons license and indicate if changes were made.

The images or other third party material in this chapter are included in the chapter's Creative Commons license, unless indicated otherwise in a credit line to the material. If material is not included in the chapter's Creative Commons license and your intended use is not permitted by statutory regulation or exceeds the permitted use, you will need to obtain permission directly from the copyright holder.



